\title{
Meningkatkan Perilaku Prososial melalui Layanan Bimbingan Kelompok dengan Menggunakan Teknik Permainan (Games) pada Anak Asrama Sion Salatiga
}

\author{
Lilis Yuliani ${ }^{1}$, Yari Dwikurnaningsih ${ }^{2}$, Setyorini ${ }^{3}$ \\ 1,2,3 Bimbingan dan Konseling, Universitas Kristen Satya Wacana Salatiga, Indonesia \\ e-mail: lilisyulliani@gmail.com¹, yari.dwikurnaningsih@staff.uksw.edu², \\ setyorini@staff.uksw.edu ${ }^{3}$
}

\begin{abstract}
Abstrak
Penelitian ini menggunakan jenis penelitian eksperimen semu, bertujuan untuk mengetahui signifikansi peningkatan perilaku prososial melalui layanan bimbingan kelompok dengan menggunakan teknik permainan (games) pada anak Asrama Sion Salatiga. Subjek penelitian adalah 11 anak yang mempunyai perilaku prososial rendah dan sangat rendah. Subjek penelitian dibagi menjadi dua kelompok yang diambil secara random dan masuk dalam kelompok eksperimen dan kelompok kontrol. Yang masing-masing kelompok terdiri dari 6 anak masuk dalam kelompok eksperimen dan 5 anak masuk dalam kelompok kontrol. Alat ukur yang digunakan adalah skala perilaku prososial yang diadaptasi oleh (Dayakisni. 2009), berdasarkan teori Einsberg \& Mussen. Analisis data untuk menguji perbedaan perilaku prososial menggunakan analisis Mann Whitney. Dari hasil analisis data setelah post test, diperoleh $p=$ $0,035<0,050$ dengan hasil mean rank post test kelompok eksperimen sebesar 7,92 dan mean rank post test kelompok kontrol sebesar 3,70. Selisih mean rank post test antara kelompok eksperimen dengan kelompok kontrol sebesar 4,22. Dengan demikian dapat disimpulkan bahwa layanan bimbingan kelompok secara signifikan dapat meningkatkan perilaku prososial anak asrama Sion Salatiga.
\end{abstract}

Kata Kunci: Perilaku Prososial, Bimbingan Kelompok, Permainan (games)

\begin{abstract}
Abstrack
This research uses quasi-experimental research, aims to determine the significance of the increase in prosocial behavior through guidance service groups using the technique of playing (games) in children of Sion Dormitory Salatiga. The research subjects were 11 children who had low and very low prosocial behavior. Research subjects were divided into two groups taken randomly and included in the experimental group and the control group. Each group consisted of 6 children in the experimental group and 5 children in the control group. The measuring instrument used is the prosocial behavior scale adapted by (Dayakisni. 2009), based on Einsberg \& Mussen's theory. Differences data analysis in prosocial behavior use Mann Whitney analysis. From the results of data analysis after the post test, obtained $p=0.035$ $<0.050$ with the mean rank results of the post-test experimental group at 7.92 and the mean rank control group post-test at 3.70. Posttests mean rank difference between the experimental group and control group by 4.22. Thus it can be concluded that group guidance services can significantly improve the prosocial behavior of the Salatiga Sion dormitory children.
\end{abstract}

Keywords : Prosocial behavior, Guidance Group, games (games) 


\section{Pendahuluan}

Perilaku menolong atau yang sering disebut dengan perilaku prososial adalah segala bentuk perilaku yang memberikan konsekuensi bagi si penerima, baik dalam bentuk materi, fisik ataupun psikologis tetapi tidak memiliki keuntungan yang jelas bagi pemiliknya (Dayakisni, 2009:176). Menurut Permata Sari (2013) manusia pada hakekatnya adalah makhluk sosial yang senantiasa mempunyai untuk berinteraksi dengan lingkungan sekitar, sehingga dapat dikatakan bahwa individu mempunyai ketergantungan dan saling membutuhkan satu sama lain. Begitu pula dengan remaja, masa remaja ditandai dengan adanya perkembangan dari segi fisik, psikis, dan sosial. Berkaitan dengan hubungan sosial pada remaja, hampir seluruh waktu yang digunakan para remaja adalah untuk bersosialisasi dengan lingkungannya baik dengan orang tua, guru, saudara, teman maupun orang lain.

Untuk meningkatkan perilaku prososial menggunakan layanan bimbingan kelompok. Menurut Melinasari (2016) bimbingan pada hakikatnya bertujuan memberikan bantuan kepada seluruh siswa agar mereka tercapai dalam hal penyesuaian diri, perkembangan yang optimal, serta menjadi individu yang lebih mandiri. Layanan bimbingan dan konseling yang tepat dalam meningkatkan kecerdasan emosi siswa adalah dengan menerapkan layanan bimbingan kelompok melalui teknik simulasi permainan. Kegiatan ini akan mengungkap pengaruh pemberian layanan tersebut terhadap peningkatan kecerdasan emosi siswa. Menurut Tri Utomo (2018), bimbingan kelompok merupakan salah satu kegiatan layanan bimbingan dan konseling yang banyak dipakai karena lebih efektif dalam pelaksanaannya. Bimbingan kelompok dengan teknik permainan dapat dilaksanakan dengan beberapa orang siswa yang tergabung dalam kelompok sehingga dapat lebih mengefisienkan waktu. Selain itu, layanan ini juga mengandung aspek sosial untuk dapat berinteraksi satu dengan yang lainnya dan bisa saling belajar bersama. Tujuan layanan bimbingan kelompok yaitu sesuai dengan arah penelitiannya itu mampu berkembangnya kemampuan sosial anak, khususnya kemampuan komunikasi dalam hal ini pengembangan perilaku prososial anak, fungsi layanan bimbingan kelompok sesuai dengan arah penelitiannya itu pemahaman dan pengembangan. Dengan bimbingan kelompok, anak akan belajar bagaimana terlibat aktif dalam kelompok, berpendapat dengan jujur dan terbuka, menghargai pendapat orang lain, tidak memaksakan kehendak dan menyampaikan maksud dan tujuan dengan cara yang baik.

Peneliti menggunakan teknik permainan karena tujuan permainan sesuai dengan arah penelitiannya yaitu untuk membantu individu meningkatkan perkembangan sosialnya. Permainan itu bersifat sosial, melibatkan proses belajar, mematuhi peraturan pemecahan masalah, disiplin diri dan kontrol emosional maupun adopsi peran-peran pemimpin dengan pengikut yang kesemuanya merupakan komponen penting dari sosialisasi (Serok \& Blum, 1993; Rusmana 2009). Permainan memberi kesempatan untuk mengekspresikan agresi dalam cara-cara yang dapat diterima secara sosial. Melalui permainan yang melibatkan kehadiran orang lain, maka secara tidak langsung sosialisasi, dan kerjasama anak akan terbentuk sehingga perilaku prososial anak akan meningkat.

\section{Perilaku prososial}

Menurut Einsberg \& Mussen (dalam Dayakisni, 2009) memberi pengertian perilaku prososial mencakup pada tindakan-tindakan: sharing (berbagi), cooperating (kerjasama), helping (membantu), donating (memberi), dan Honesty (kejujuran).

Perilaku prososial memiliki intensi untuk mengubah keadaan fisik atau psikologis penerima bantuan dari kurang baik menjadi lebih baik. Dalam arti secara material maupun psikologis. Dalam hal ini dapat dikatakan bahwa perilaku prososial bertujuan untuk membantu meningkatkan well being orang lain menurut Staub dalam Dayakisni (2009: 175). Dalam perilaku prososial terdapat beberapa aspek yang dikemukakan oleh Einsberg \& Mussen (dalam Dayakisni, 2009) yaitu: sharing (berbagi), cooperating (kerjasama), helping (membantu), donating (memberi), honesty (kejujuran). Dari kelima hal tersebut jika terus dipupuk dan dilakukan akan membuat hidup setiap orang berperilaku prososial dengan baik. Menurut Hikma (2018) perilaku prososial adalah suatu tindakan menolong yang menguntungkan orang lain tanpa harus menyediakan suatu keuntungan langsung pada orang yang melakukan tindakan tersebut, dan mungkin melibatkan suatu resiko bagi orang yang menolong. Bentuk - bentuk perilaku yang mengindikasikan perilaku prososial yaitu menolong, berbagi, kerja sama, empati dan jujur kepada orang lain. Menurut Baron (2005:96) perilaku prososial suatu tindakan menolong yang menguntungkan orang lain tanpa harus menyediakan suatu keuntungan langsung pada orang yang melakukan tindakan tersebut, dan mungkin bahkan melibatkan suatu resiko bagi orang yang menolong. Penjelasan tersebut sejalan dengan pernyataan pada penelitian Yuli Asih (2010) dimana perilaku prososial merupakan salah satu bentuk perilaku yang muncul dalam kontak sosial, sehingga perilaku prososial merupakan tindakan yang dilakukan atau direncanakan untuk menolong orang lain tanpa mempedulikan motif-motif si penolong. Tindakan menolong 
sepenuhnya dimotivasi oleh kepentingan sendiri tanpa mengharapkan sesuatu untuk dirinya. Tindakan prososial lebih menuntut pada pengorbanan tinggi dari si pelaku dan bersifat sukarela atau lebih ditunjukkan untuk menguntungkan orang lain daripada untuk mendapatkan imbalan materi maupun sosial. Dan dari penelitian Khotim (2014) perilaku prososial adalah tindakan sukarela yang dilakukan sesorang atau sekelompok orang untuk menolong orang lain baik keadaan fisik maupun psikologis, meliputi segala bentuk tindakan-tindakan menolong, bekerja sama, berbagi perasaan, bersikap jujur dan bertindak dermawan terhadap orang lain.

Berdasarkan hal tersebut, perilaku prososial merupakan perilaku menolong yang menguntungkan bagi orang lain yang dimotivasi oleh diri sendiri untuk mengubah keadaan fisik maupun psikologis penerima bantuan dari kurang baik menjadi lebih baik, tetapi tidak memiliki keuntungan yang jelas bagi pelakunya.

\section{Bimbingan Kelompok}

Kegiatan bimbingan kelompok akan terlihat hidup jika di dalamnya terdapat dinamika kelompok. Dinamika kelompok merupakan media efektif bagi anggota kelompok dalam mengembangkan aspek-aspek positif dalam mengembangkan kepercayaan diri yang positif.

Menurut Sukardi (2002: 48),"layanan bimbingan kelompok adalah layanan yang memungkinkan sejumlah peserta didik secara bersama-sama memperoleh bahan dari narasumber tertentu (terutama guru pembimbing atau konselor) yang berguna untuk menunjang kehidupan sehari-hari baik individu sebagai pelajar, anggota keluarga, dan masyarakat serta untuk mempertimbangkan dalam pengambilan keputusan".

Dalam pelaksanaan layanan bimbingan kelompok, terdapat tahapan-tahapan yang telah diungkapkan oleh Prayitno (2004:18), yaitu tahap pembentukan, tahap peralihan, tahap kegiatan dan tahap pengakhiran. Suatu proses layanan sangat ditentukan pada tahap-tahap yang harus dilalui sehingga terarah, runtut, dan tepat sasaran.

\section{Bimbingan Kelompok untuk Mengembangkan Perilaku Prososial}

Layanan bimbingan kelompok dirasa sangat tepat, karena melalui layanan bimbingan kelompok anak diminta untuk mengeluarkan pendapat, ide, gagasan, serta saling memberikan perhatian dan motivasi sehingga siswa dengan kegiatan diskusi dapat memperlancar komunikasinya dan mendapatkan penguatan untuk mengembangkan keaktifan dan potensi diri secara optimal. Melalui layanan bimbingan kelompok ini menuntut anak untuk terlibat aktif, secara tidak langsung dapat melatih keaktifan anak dalam kegiatan diskusi. Melalui interaksi dalam pelaksanaan layanan bimbingan kelompok diharapkan anak menjadi terpacu untuk mengembangkan diri terutama bagi anak yang memiliki perilaku prososial yang rendah.

\section{Teknik Permainan (games)}

Menurut Serok \& Blum, 1993; Rusmana, 2009 (dalam Suwarjo, 2012) menyatakan bahwa permainan (games) bersifat sosial, melibatkan proses belajar, mematuhi peraturan, pemecahan masalah, disiplin diri dan control emosional dan adopsi peran-peran pemimpin dengan pengikut yang kesemuanya merupakan komponen penting dari sosialisasi. Games memberi kesempatan untuk mengekspresikan agresi dalam cara-cara yang dapat diterima secara sosial. Hal ini menurut Milberg 1976 (dalam Suwarjo, 2012) sesuai dengan teori yang mengatakan bahwa permainan (games) yang diciptakan oleh manusia untuk memberikan keluaran-keluaran (outlets) kemarahan dan permusuhan yang dapat diterima yang merupakan jiplakan dari respons bertempur atau berkelahi. Menurut Yuli Indraswari (2013) teknik bermain merupakan salah satu teknik dalam bimbingan kelompok yang dilakukan dengan kesenangan dan suka rela untuk melampiaskan ketegangan-ketegangan yang terjadi sehingga anak bisa mencapai perkembangan psikis, fisik, emosi dan iletektual.

Pada intinya kegiatan permainan dalam Bimbingan dan Konseling adalah memberikan makna pembelajaran secara tidak langsung melalui permainan yang dilaksanakan bersama anak. Adanya pemaknaan dibalik perminan sebagai bahan refleksi diri membuat anak lebih mengerti akan maksud dan tujuan pemberian permainan.

\section{Metode}

Subjek yang diambil dalam penelitian ini adalah 11 anak asrama Sion Salatiga. Subyek diambil melalui hasil data dari penyebaran skala sikap perilaku prososial yang disebarkan oleh semua anak asrama Sion Salatiga yang berjumlah 20 anak dan diketahui anak yang memiliki perilaku prososial rendah dan sangat rendah berjumlah 11 anak yang terdiri dari 5 anak sebagai kelompok kontrol dan 6 anak sebagai kelompok eksperimen. 
Tabel 1. Rancangan Penelitian

\begin{tabular}{lccc}
\multicolumn{1}{c}{ Grup } & Pre Test & Perlakuan & Post test \\
\hline Eksperimen & $\mathrm{O} 1$ & $\mathrm{X}$ & $\mathrm{O} 2$ \\
Kontrol & $\mathrm{O} 3$ & - & $\mathrm{O} 4$ \\
\hline
\end{tabular}

Keterangan:

O1 : Pre test tentang perilaku prososial untuk kelompok eksperimen

O3 : Pre tentang perilaku prososial untuk kelompok kontrol

$\mathrm{X}$ : Pemberian treatment Bimbingan Kelompok dengan teknik permainan

- $\quad$ : Tidak diberikan treatment

O2 : Post test tentang perilaku prososial untuk kelompok eksperimen

O4 : Post test tentang perilaku prososial untuk kelompok eksperimen

Alat pengumpul data yang digunakan adalah skala perilaku prososial yang disusun berdasarkan aspek-aspek perilaku prososial menurut Saifudin 1999.

\section{Hasil dan Pembahasan}

Dalam penelitian ini, pemberian treatment kepada kelompok eksperimen dengan 8 topik yang berhubungan dengan perilaku prososial sebanyak 8 kali pertemuan.

Tabel 2. Perbandingan Hasil Post Test

\begin{tabular}{cccc}
\hline Interval & Kategori & Kelompok Eksperimen & Kelompok Kontrol \\
\hline $78-85$ & Sangat tinggi & 2 & 0 \\
$73-77$ & Tinggi & 4 & 2 \\
$68-72$ & Sedang & 0 & 3 \\
$63-67$ & Rendah & 0 & 0 \\
$58-62$ & Sangat rendah & 0 & 0 \\
\hline \multicolumn{2}{c}{ Total } & 6 & 5 \\
\hline
\end{tabular}

Tabel 3. Perbedaan Mean Rank Kelompok Eksperimen dan Kelompok Kontrol

\begin{tabular}{|c|c|c|c|}
\hline \multicolumn{4}{|c|}{ Ranks } \\
\hline Kelompok & $\mathrm{N}$ & Mean Rank & Sum Of Ranks \\
\hline Kelompok Eksperimen & 6 & 7.92 & 47.50 \\
\hline Kelompok Kontrol & 5 & 3.70 & 18.50 \\
\hline Total & 11 & & \\
\hline
\end{tabular}

Tabel 4. Signifikansi Pre Tes Perilaku Prososial

Test Statistics $^{\mathrm{a}}$

\begin{tabular}{lr} 
& Perilaku prososial \\
\hline Mann-Whitney U & 10.000 \\
Wilcoxon W & 25.000 \\
Z & -.923 \\
Asymp. Sig. (2-tailed) & .356 \\
Exact Sig. [2*(1-tailed Sig.)] & $429^{\mathrm{b}}$ \\
\hline
\end{tabular}
a. Grouping Variable: kelompok
b. Not corrected for ties. 
Tabel 5. Signifikansi Post Test Perilaku Prososial

Test Statistics ${ }^{\mathrm{a}}$

\begin{tabular}{lr}
\hline & Hasil \\
\hline Mann-Whitney U & 3.500 \\
Wilcoxon W & 18.500 \\
Z & -2.104 \\
Asymp. Sig. (2-tailed) & .035 \\
Exact Sig. [2*(1-tailed Sig.)] & $.030^{\mathrm{b}}$ \\
\hline
\end{tabular}

a. Grouping Variable: kelompok

b. Not corrected for ties.

Perbedaan tersebut dapat dilihat hasil post test dengan nilai $p=$ Asymp. Sig (2-tailed $0,035<0,050$, serta dapat dilihat dari rata-rata mean kelompok eksperimen mengalami perbedaan yang signifikan sesudah eksperimen yaitu: 4,22.

Terjadinya perbedaan tersebut menunjukan ada peningkatan yang signifikan perilaku prososial anak asrama Sion Salatiga melalui layanan bimbingan kelompok menggunakan teknik permainan. Temuan ini sejalan dengan pandangan yang dikemukakan oleh Einsberg \& Mussen (dalam Dayakisni, 2009) yaitu: sharing (berbagi), cooperating (kerjasama), helping (membantu), donating (memberi), honesty (kejujuran). Dari kelima hal tersebut jika terus dipupuk dan dilakukan akan membuat hidup setiap orang berperilaku prososial dengan baik. Dalam hal ini peneliti menjabarkan kelima aspek tersebut yang diberikan melalui layanan bimbingan kelompok menggunakan teknik permainan untuk meningkatkan perilaku prososial.

Hasil penelitian ini mendukung dengan temuan pada penelitian Suriyah Nugraheni, (2013) yang berjudul "Penggunaan Teknik Permainan dalam Meningkatkan Perilaku Prososial Siswa di Kelas VIII D SMP N 1 Suruh Tahun Pelajaran 2012/2013" terdapat 20 siswa yang memiliki perilaku prososial yang rendah dan sangat rendah kemudian dibagi menjadi 2 kelompok yaitu 10 siswa masuk ke dalam kelompok eksperimen dan 10 siswa masuk ke dalam kelompok kontrol untuk. Dijelaskan dari pengolahan hasil uji statistik post test antara kelomompok eksperimen dan kelompok kontrol dengan teknik Mann Whitney diperoleh hasil bahwa Asymp. Sig. (2-tailed) 0,012<0,050 dengan mean rank post test kelompok eksperimen adalah 13,60 sedangkan mean rank post test kelompok kontrol adalah 7,40. Dengan demikian ada perbedaan yang signifikan antara kelompok eksperimen dan kelompok kontrol dan terjadi peningkatan yang signifikan perilaku prososial pada kelompok eksperimen. Untuk hasil mean rank pre-test dan post test kelompok eksperimen dijelakkan hasil uji Mann Whitney kelompok eksperimen diperoleh mean rank pre-test sebesar 6,10 dan mean rank post test sebesar 14,90 dan signifikansi yang ditunjukkan yaitu Asymp. Sig. (2-tailed) 0,001<0,050. Dengan demikian, dapat disimpulkan bahwa penggunaan teknik permainan secara signifikan dapat meningkatkan perilaku prososial anak, dan dalam penelitian ini teknik permainan dapat meningkatkan perilaku prososial anak.

\section{Kesimpulan}

Berdasarkan hasil analisis, maka kesimpulan penelitian ini adalah bahwa layanan bimbingan kelompok dengan teknik permainan secara signifikan dapat meningkatkan perilaku prososial pada anak asrama Sion Salatiga, dengan $p=$ Asymp. Sig. 0,035<0,050.

Berdasarkan hasil penelitian yang telah dipaparkan pada bab sebelumnya, maka peneliti menemukan beberapa hal penting yang perlu dipertimbangkan, yaitu:

1) Bagi Pengasuh

Pengasuh hendaknya menggunakan layanan bimbingan kelompok dengan teknik permainan untuk meningkatkan perilaku prososial anak asrama Sion Salatiga.

2) Bagi Konselor

Penelitian ini hendaknya bermanfaat bagi konselor dalam meningkatkan program layanan bimbingan kelompok dengan teknik permainan (games) untuk meningkatkan perilaku prososial anak.

3) Bagi Peneliti Selanjutnya

Penelitian ini hendaknya dapat menjadi referensi bagi peneliti selanjutnya dan dapat lebih kreatif di dalam memilih teknik permainan, serta mempertimbangkan waktu, subjek dan tempat penelitian yang baik. 


\section{Daftar Pustaka}

Agustin, Adhi Krisna Maria. 2014. Meningkatkan Perilaku Prososial Anak Usia 10-12 Tahun Melalui Terapi Bermain di PPA Agape 10-847 Salatiga. Skripsi. Universitas Kristen Satya Wacana.

A. T, Andi Mappiare. 2006. Kamus Istilah Konseling dan Terapi. Jakarta: PT Raja Grafindo.

Arikunto, Suharsimi. 2006. Prosedur Penelitian Suatu Pendekatan Praktek. Jakarta: Rineka Cipta.

Azwar, Syaifudin. 2005. Penyusunan Skala Psikologi. Yogyakarta: Pustaka Pelajar

Baron, R.A. dan D. Byrne. 2005. Psikologi Sosial. Jakarta: PT. Gelora Aksara Pratama.

Dayakisni, T. dan Hudaniah. 2009. Psikologi Sosial. Malang: UMM Press.

Hikma, dkk. 2018. Meningkatkan Perilaku Prososial melalui Teknik Sosiodrama pada Siswa Kelas VII H SMP Negeri 3 Palu. Jurnal Konseling \& Psikoedukasi Vol. 3 No. 1 Hal. 8898. http://jurnal.untad.ac.id/jurnal/index.php/JKP. Diakses 20 Mei 2019.

Khotim, Nilawatul. 2014. Penerapan Bimbingan Kelompok Teknik Sosiodrama Untuk Meningkatkan Perilaku Prososial Siswa Kelas X Tkj-1 (Teknik Komputer Jaringan 1) Smk Raden Rahmat Mojosari Mojokerto. Jurnal BK UNESA Vol. 4 No. 3 Hal. 410-418. http://jurnalmahasiswa.unesa.ac.id/index.php/jurnal-bk-unesa/article/view/8393. Diakses 20 Mei 2019.

Melianasari, Dewi. 2016. Penerapan Layanan Bimbingan Kelompok melalui Teknik Permainan Simulasi dan untuk Meningkatkan Kecerdasan Emosi Siswa. Pedagogia : Jurnal IImu Pendidikan. http://ejournal.upi.edu/index.php/pedagogia/article/view/3880. Diakses 20 Mei 2019.

Mugiarso, H. 2009. Bimbingan dan Konseling. Semarang: UNNES Press.

Myers, David G. 2012. Psikologi Sosial. Jakarta: Salemba Humanika.

Nugraheni, Suriyah. 2013. Penggunaan Teknik Permainan Dalam Meningkatkan Perilaku Prososial Siswa di Kelas VIII D SMP Negeri 1 Suruh Tahun Pelajaran 2012/2013. Skripsi. Universitas Kristen Satya Wacana.

Pandansari, Reza. 2007. Efektivitas Bimbingan Kelompok Dalam Upaya Mengembangkan Sikap Prososial Pada Siswa Kelas X SMA Teuku Umar Semarang Tahun Ajaran 2006/2007. Skripsi. Universitas Negeri Semarang.

Permata Sari, Erlina. 2013. Pengembangan Model Layanan Bimbingan Kelompok dengan Teknik Sosiodrama untuk Meningkatkan Sikap Prososial. Jurnal Bimbingan Konseling 2 (2) Hal. 79-84. http://journal.unnes.ac.id/sju/index.php/jubk. Diakses 20 Mei 2019.

Pica, Rae. 2012. Permainan-Permainan Pengembangan Karakter Anak-Anak. Jakarta Barat: Permata Puri Media.

Prayitno \& E. Amti. 2004. Dasar-Dasar Bimbingan dan Konseling. Jakarta: Rineka Cipta.

Rini, Anik, Mahtun, F. 2015. Pengaruh Bimbingan Kelompok Terhadap Perilaku Prososial Siswa Kelas VIII SMP Negeri 7 Semarang.Skripsi.Universitas Negeri Semarang.

Santrock, J.W. (2007). Psikologi Perkembangan. Edisi 11 Jilid 1. Jakarta: Erlangga 
Saputro, Heri \& Intan Fazrin. Anak Sakit Wajib Bermain Di Rumah Sakit Penerapan Terapi Bermain Anak Sakit; Proses, Manfaat dan Pelaksanaannya. Ponorogo: Forum IImiah kesehatan (FORIKES).

Suwarjo dkk. 2012. 55 Permainan (games) dalam Bimbingan dan Konseling. Yogyakarta: Paramitra Publishing.

Tri Utomo, Evriyen, dkk. 2018. Penggunaan Layanan Bimbingan Kelompok Teknik Permainan untuk Meningkatkan Kemampuan Regulasi Emosi Siswa. Jurnal Bimbingan Konsling Vol 6 No 3 http://jurnal.fkip.unila.ac.id/index.php/ALIB/article/view/16955. Diakses 20 Mei 2019.

Yuli Asih, Gusti, Margaretha Maria Shinta Pratiwi. 2010. Perilaku Prososial Ditinjau dari Empati dan Kematangan Emosi. Jurnal Psikologi Universitas Muria Kudus Vol. I No 1. http://eprints.umk.ac.id/268/1/33_-_42.PDF. Diakses 20 Mei 2019.

Yuli Indraswari, Fauziah, Titin Indah Pratiwi. 2013. Penerapan Bimbingan Kelompok dengan Teknik Permainan Kerja Sama untuk Meningkatkan Kemampuan Interaksi Sosial Siswa Kelas X-1 SMA Negeri 3 Lamongan. Jurnal BK UNESA Vol. 01 No. 01 208-215. https://media.neliti.com/media/publications/. Diakses 20 Mei 2019. 